\title{
AN INNOVATIVE Fog CATCHER SYSTEM APPLIED IN THE ANDEAN COMMUNITIES OF ECUADOR
}

\author{
D. V. Carrera-Villacrés, I. C. Robalino, F. F. Rodríguez, \\ W. R. Sandoval, D. L. Hidalgo, T. Toulkeridis
}

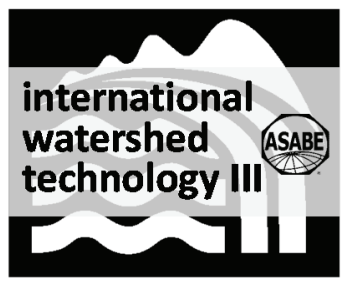

\begin{abstract}
Fog catchers have been successfully applied in several countries around the world. In Ecuador, the Galte communities in the Andean region suffer from water deficits because they are located at an altitude higher than $3500 \mathrm{~m}$ above sea level. Rainfall in the area is relatively low, about $600 \mathrm{~mm}$ per year, with high evapotranspiration of approximately $615.74 \mathrm{~mm}$ per year. This study aimed to install fog catchers in Galte in 2014 and 2015 to help meet the communities' water needs. The fog catcher system was designed to satisfy the irrigation water demand for local agricultural production, mainly maize, based on estimates using the Blaney-Criddle method. Every day throughout the year, each fog catcher collected 5 to $20 \mathrm{~L}$ of water per $\mathrm{m}^{2}$ of catcher area. The results indicate that the fog catcher system can meet about $5 \%$ of the local water demand for agricultural production.
\end{abstract}

Keywords. Ecuador, Evaporation, Evapotranspiration, Precipitation, Water deficit.

$\mathrm{T}$ The global water shortage is not new, and it is increasing every year. According to the United Nations, 1.8 billion people will be living in countries or regions with absolute water scarcity by the year 2025 , and in 2030, nearly half of the world's population will live in areas of water stress. Worldwide, survival often depends on the proximity and accessibility of fresh water. Only a small fraction (less than 1\%) of fresh water is accessible. The rest remains trapped in frozen environments, such as glaciers and ice caps, or suspended in the atmosphere. Therefore, it has been a priority to search for new supply systems to provide the water needed for arid or relatively dry sites, which are traditionally isolated from central water supplies. Among the systems proposed to address this shortage, fog catchers can provide a relatively accessible water supply in elevated zones, where a high proportion of this natural resource may be collected (Hering et al., 1987; Schemenauer and Cereceda, 1991; Fuzzi et al., 1997; Regalado and Ritter, 2016). A fog catcher can economically extract water that can be used by the surrounding villages (Pajares et al., 2011;

(c) $(9) \Theta$ The authors have paid for open access for this article. This (c) $\mathrm{BY}$ NC ND work is licensed under a Creative Commons AttributionNonCommercial-NoDerivatives 4.0 International License https:/crea tivecommons.org/licenses/by-nc-nd/4.0/

Submitted for review in March 2017 as manuscript number NRES 12368; approved for publication as part of the "International Watershed Technology" collection by the Natural Resources \& Environmental Systems Community of ASABE in August 2017.

The authors are David V. Carrera-Villacrés, Professor, I. Carolina Robalino, Professor, Fabian F. Rodriguez, Professor, Washington R. Sandoval, Professor, Deysi L. Hidalgo, Graduate Student, and Theofilos Toulkeridis, Professor, Universidad de las Fuerzas Armadas ESPE, Departamento de Ciencias de la Tierra y la Construcción, Grupo de Investigación en Contaminación Ambiental (GICA), Sangolquí, Ecuador. Universidad Central de Ecuador, FIGEMPA, Quito, Ecuador, and Facultad de Economía, Pontificia Universidad Católica del Ecuador, Quito, Ecuador. Corresponding author: David V. Carrera-Villacrés, Av. Gral. Rumiñahui S/N, Sangolquí, Pichincha, Ecuador; phone: 593-23989400, ext. 1701; e-mail: dvcarrera@espe.edu.ec.
WMO, 2011). This technique has been applied successfully in a variety of dry or arid regions in Guatemala (Frigerio, 1990), Chile (Schemenauer and Cereceda, 1992; Suau, 2010), Peru (Pinche and Ruiz, 1996; Williams, 2015), Panama (Cavelier et al., 1996), Puerto Rico (Schellekens et al., 1998), South Africa (Olivier, 2002), Namibia (Shanyengana et al., 2002), Spain (Jaen, 2002; Ritter et al., 2008), Iran (Mousavi-baygi, 2008), and Saudi Arabia (Cereceda et al., 2014), among several others.

The Andean communities of Ecuador suffer water stress because they are located above $3500 \mathrm{~m}$ a.s.l., where there is a water deficit. Nonetheless, this region appears to have enough water due to the fog conditions (Palmira, 2015). While these communities depend on agriculture and livestock production, their production methods lack technological support as well as soil and water conservation programs, resulting in low productivity and precarious living conditions. To improve these conditions, it is necessary to improve the water supply, which will result in higher agricultural production and better living conditions.

Therefore, this study aims to implement a new fog catcher system in the communities of Yaguachi and Galte (fig. 1), which are located in Palmira Parish in Chimborazo Province, which is part of the Ecuadoran Andes, where water deficit is a daily problem. This study first determined the demand for irrigation water, especially for maize, which is the main component of the local diet but also has high water requirements. Furthermore, we generated weather data to calculate the ability of a fog catcher to trap condensation from the atmosphere. Additionally, we determined the precipitation, evaporation, and evapotranspiration in the area, which yield better understanding of the water lost by these factors, and conducted surveys to determine the amount of water required by the local communities and their crops. The location and installation of a fog catcher is shown in figure 3. 

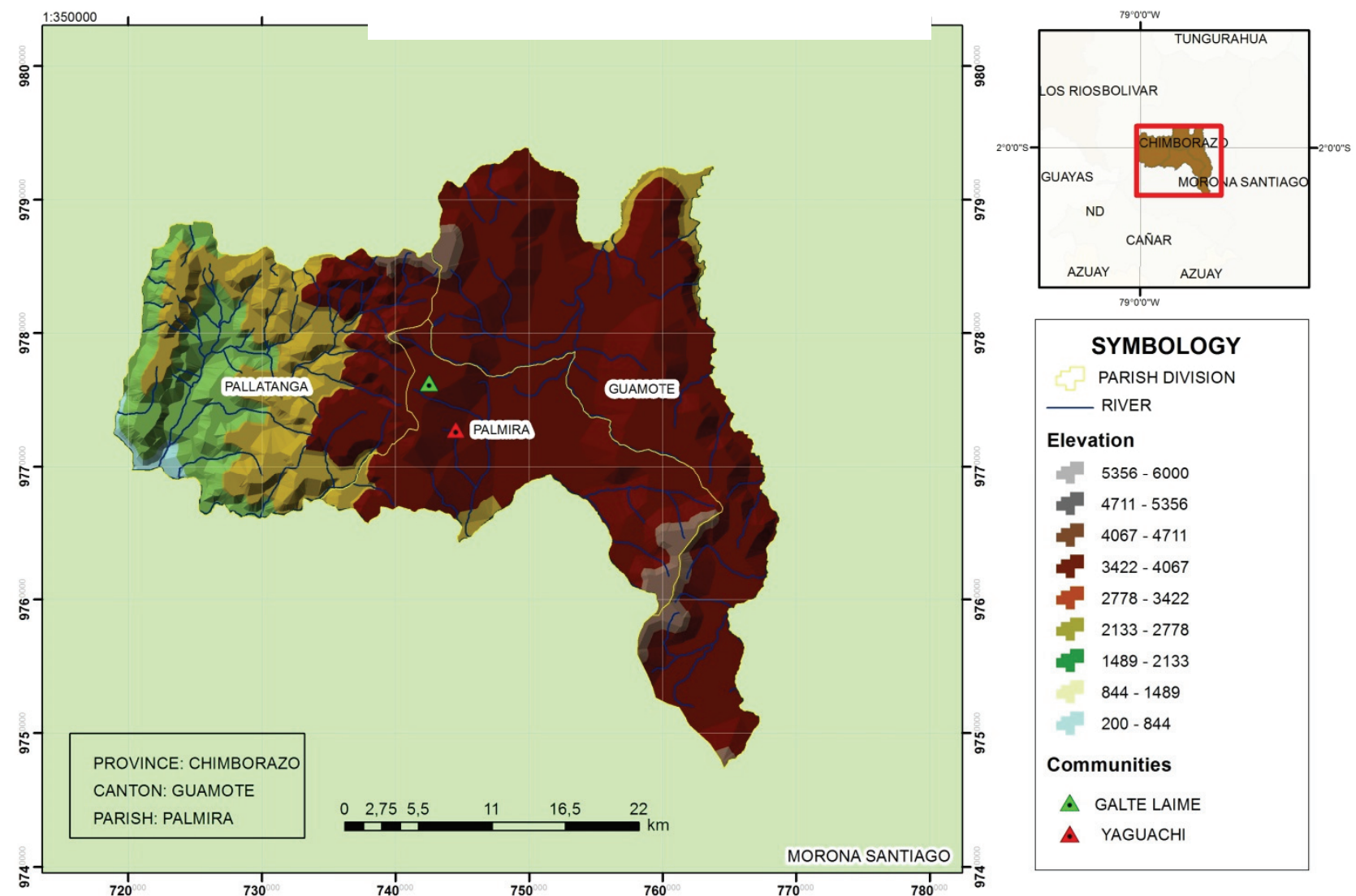

Figure 1. Locations of the communities of Galte and Yaguachi. The map was created with ArcGIS 9.3 in the Remote Sensing and Geomatics Laboratory of Universidad de las Fuerzas Armadas, with free access obtained from the Geoportal of the Military Geographic Institute of Ecuador (IGM, 2013). Field work using GPS Navigator was done with the help of the communities.

\section{Materials ANd Methods \\ DATA GENERATION}

The weather parameters needed to determine the existing water shortages in the area, as well as for the design of the fog catcher system, included precipitation, temperature, sunshine hours, relative humidity, and wind speed. These parameters were measured with two weather stations. Because there was no altitude difference between the two weather stations, there was also no climatic difference between them. Because the fog catchers use the same design and methodology, they demonstrated a high correlation between the weather stations (Schemenauer et al., 2005; Carrera-Villacrés et al., 2016). Meteorological data, including precipitation, sunshine hours, temperature, wind speed, and relative humidity, were also obtained from the National Institute of Meteorology and Hydrology (INAMHI) of Ecuador (fig. 2).

To determine the water deficit and evaporation, monthly precipitation data, measured over ten years, were used in applying the Wilson nomogram (Wilson, 1974; Aparicio, 2012). Evapotranspiration, which is a key factor in the design of irrigation systems, was estimated using the Thornthwaite and Blaney-Criddle methods (Thornthwaite, 1948; Blaney and Criddle, 1950). A continuous data set was generated for the study years of 2014 and 2015. The climate data were subsequently homogenized and validated to determine their reliability, as well as the relationships between the meteorological variables (Carrera-Villacrés et al., 2016). Finally, the water collection was monitored from November 2014 through March 2015, as this period represents the rainy season in the study area.

\section{COMMUNITY SURVEY}

A survey was administered to the community, based on FogQuest (2005), that contained basic questions about the number of people living in the community, the animals they own, the types of crops they grow, and the crop land area. This survey had three major sections. The first section focused on socioeconomic information, including family size, age, education level, economic activities, and sources of income. The second section determined the main source of water, such private or state managed, among other water-related questions. Finally, the third section determined the agricultural and animal production, crop yields, and water needs for production activities. The collected information helped us determine the water required for people, animals, and crops in the community and allowed us to calculate the required size of the fog catcher system.

\section{CAPACity OF Fog CATCher System}

The location of the fog catcher system was established according to the capacity of the water container, which in this case was $250 \mathrm{~L}$. We estimated that the container needed to be filled daily. This allowed us to calculate the number of fog catchers needed in the study area. 


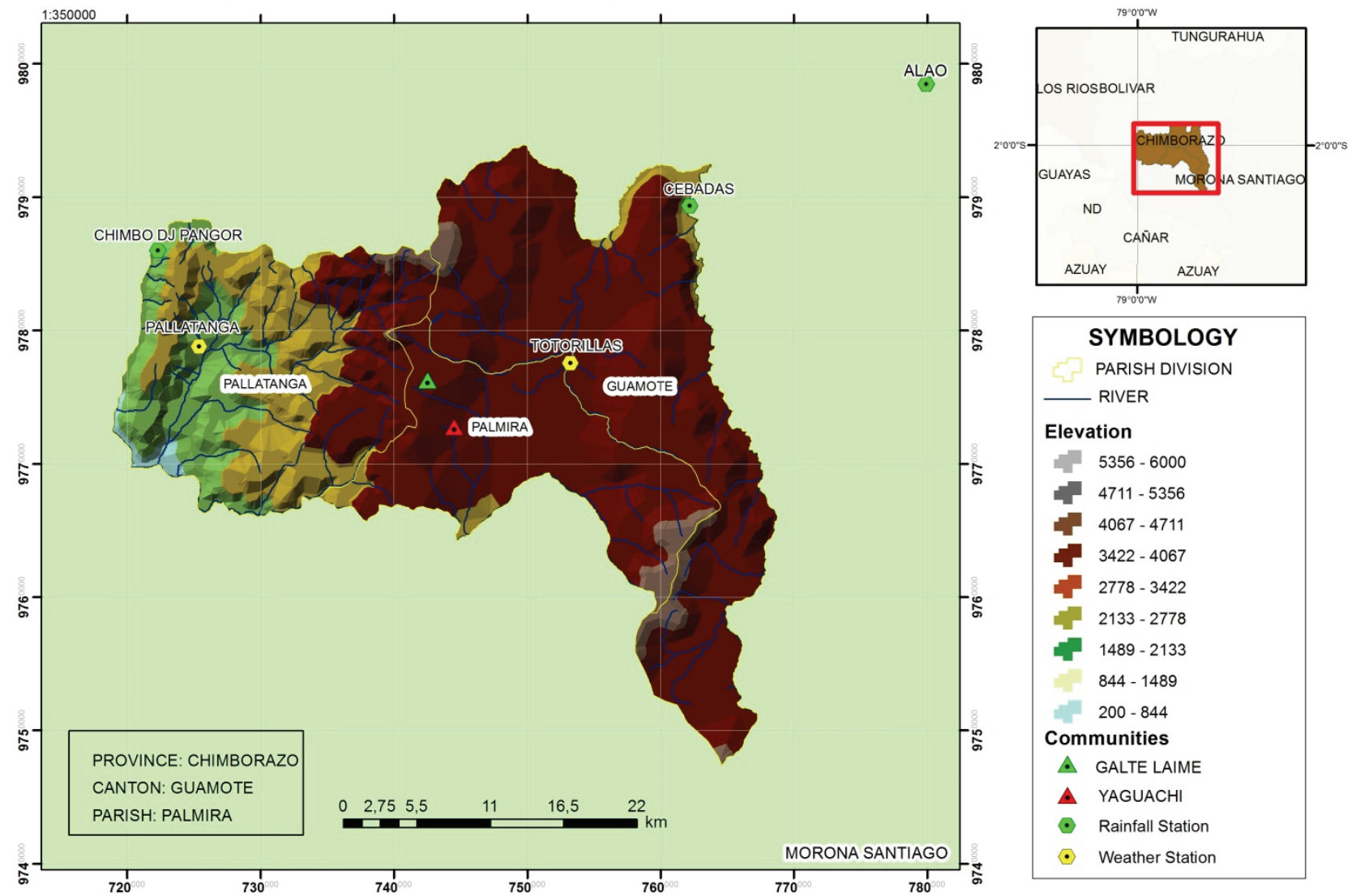

Figure 2. Locations of weather stations closest to the study area.
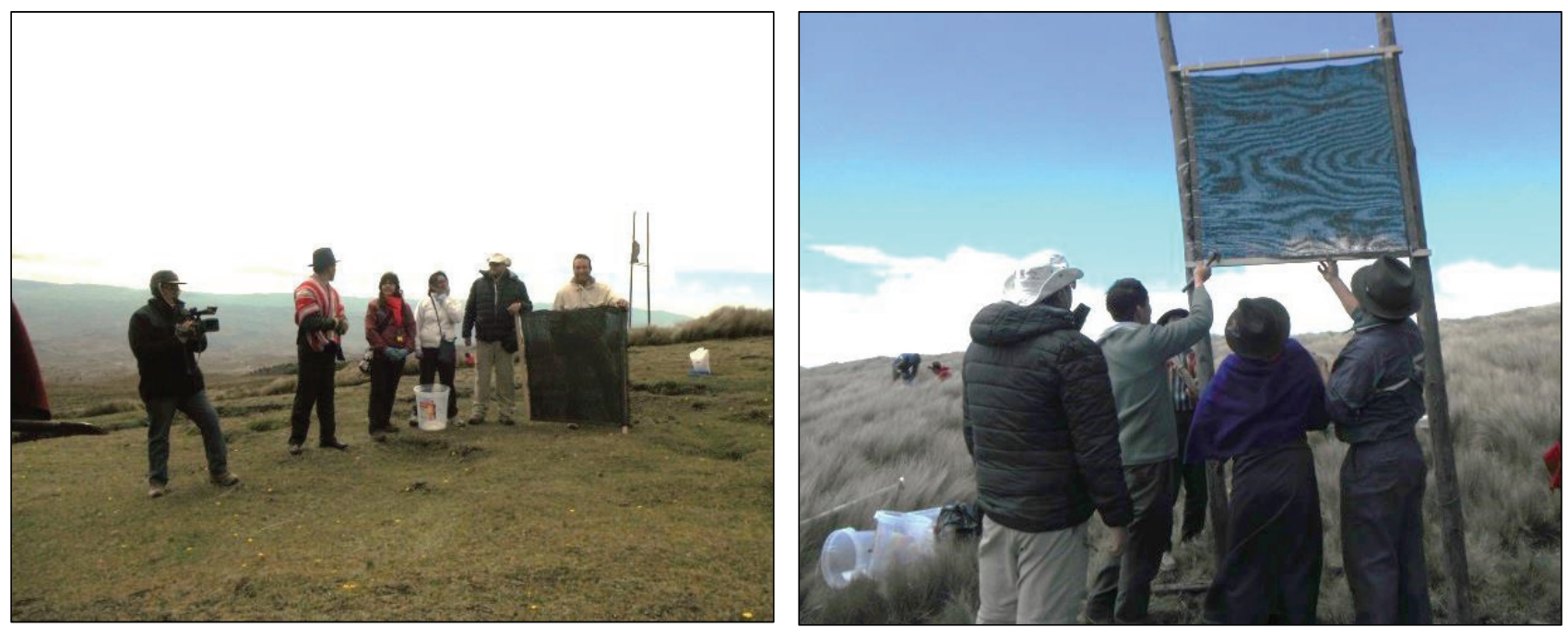

Figure 3. Training in operation (left) and placement of a fog catcher (right).

\section{RESULTS AND DISCUSSION \\ DATA GENERATION}

The weather information, with the previously described parameters, spanned a period of about ten years. However, incomplete information has been a general problem, and lack of data for some years is part of this unfortunate fact. For this study, it was necessary to apply methods that compensate for missing data. These methods were the correlation-regression method and the random sample method (Otero, 2011; Car-
rera-Villacrés et al., 2016). The incomplete rainfall information was filled in with interpolation of existing data, as illustrated in table 1.

Data homogenization was performed to estimate the precipitation, evaporation, and evapotranspiration in the study area. Figure 4 compares the curves for these parameters with the results of the Blaney-Criddle method, which is based on the cropping season, e.g., the maize season starts in September and ends in May of the following year (Blaney and Criddle, 
Table 1. Example of data filling of missing precipitation data for the Totorillas weather station (source: INAMHI, 2015).

\begin{tabular}{|c|c|c|c|c|c|c|c|c|c|c|c|c|c|}
\hline \multirow[b]{2}{*}{ Year } & \multicolumn{12}{|c|}{ Incomplete Monthly Precipitation Data } & \multirow[b]{2}{*}{ Annual Total } \\
\hline & Jan. & Feb. & Mar. & Apr. & May & June & July & Aug. & Sept. & Oct. & Nov. & Dec. & \\
\hline 2014 & 41.6 & 11.0 & 111.8 & 76.6 & 96.1 & 38.8 & 31.0 & 6.6 & 93.3 & 37.6 & 108.2 & 75.3 & 727.9 \\
\hline 2013 & 31.2 & 64.4 & 63.3 & 5.4 & 45.5 & 2.9 & 34.7 & 22.0 & 16.5 & 64.1 & 9.0 & 30.3 & 389.3 \\
\hline 2012 & 101 & 74.9 & 60.7 & 137.8 & 18.5 & 11.4 & 6.9 & 16.5 & 0.0 & 94.3 & 135.2 & 30.3 & 687.5 \\
\hline 2011 & 73.8 & 60.2 & 154.1 & 32.3 & 29.1 & 32.0 & 26.7 & 13.6 & 52.1 & 57.7 & 59.5 & 59.5 & 650.6 \\
\hline 2010 & 21.5 & 46.2 & 86.9 & 73.5 & NA & NA & NA & NA & NA & NA & NA & NA & 227.1 \\
\hline 2009 & 44.1 & 43.1 & 21.1 & 77.1 & 25.9 & 8.5 & 7.7 & 50.1 & 16.6 & 50.1 & 16.6 & NA & 360.9 \\
\hline 2008 & 36.1 & 168.3 & 72.5 & 119.0 & 102.9 & 42.0 & 21.6 & 24.0 & 17.5 & 65.0 & 19.6 & 15.0 & 703.5 \\
\hline 2007 & 47.4 & 17.4 & 112.6 & 53.6 & 31.4 & 30.0 & 10.5 & 48.5 & 0.0 & 16.2 & 32.4 & 21.8 & 421.8 \\
\hline 2006 & 51.8 & 52.1 & 97.1 & 78.4 & 4.0 & 51.6 & 2.8 & 22.9 & 4.1 & 63.9 & 83.0 & 98.1 & 609.8 \\
\hline 2005 & 280.6 & NA & NA & NA & NA & NA & NA & NA & NA & NA & NA & NA & 280.6 \\
\hline Mean & 72.91 & 58.25 & 87.23 & 70.59 & 44.39 & 29.21 & 20.19 & 23.04 & 25.48 & 52.06 & 62.23 & 55.21 & \\
\hline \multicolumn{14}{|c|}{ Complete Monthly Precipitation Data } \\
\hline Year & Jan. & Feb. & Mar. & Apr. & May & June & July & Aug. & Sept. & Oct. & Nov. & Dec. & Annual Total \\
\hline 2014 & 41.6 & 11.0 & 111.8 & 76.6 & 96.1 & 38.8 & 31.0 & 6.6 & 93.3 & 37.6 & 108.2 & 75.3 & 727.9 \\
\hline 2013 & 31.2 & 64.4 & 63.3 & 5.4 & 45.5 & 2.9 & 34.7 & 22.0 & 16.5 & 64.1 & 9.0 & 30.3 & 389.3 \\
\hline 2012 & 101 & 74.9 & 60.7 & 137.8 & 18.5 & 11.4 & 6.9 & 16.5 & 0.0 & 94.3 & 135.2 & 30.3 & 687.5 \\
\hline 2011 & 73.8 & 60.2 & 154.1 & 32.3 & 29.1 & 32.0 & 26.7 & 13.6 & 52.1 & 57.7 & 59.5 & 59.5 & 650.6 \\
\hline 2010 & 21.5 & 46.2 & 86.9 & 73.5 & 64.4 & 44.86 & 47.68 & 16.67 & 36.28 & 27.41 & 124.4 & 72.19 & 662.02 \\
\hline 2009 & 44.1 & 43.1 & 21.1 & 77.1 & 25.9 & 8.5 & 7.7 & 50.1 & 16.6 & 50.1 & 16.6 & 46.27 & 407.17 \\
\hline 2008 & 36.1 & 168.3 & 72.5 & 119.0 & 102.9 & 42.0 & 21.6 & 24.0 & 17.5 & 65.0 & 19.6 & 15.0 & 703.5 \\
\hline 2007 & 47.4 & 17.4 & 112.6 & 53.6 & 31.4 & 30.0 & 10.5 & 48.5 & 0.0 & 16.2 & 32.4 & 21.8 & 421.8 \\
\hline 2006 & 51.8 & 52.1 & 97.1 & 78.4 & 4.0 & 51.6 & 2.8 & 22.9 & 4.1 & 63.9 & 83.0 & 98.1 & 609.8 \\
\hline 2005 & 280.6 & 44.93 & 93.19 & 52.21 & 38.04 & 30.03 & 12.42 & 9.63 & 19.36 & 44.26 & 34.35 & 104.4 & 763.38 \\
\hline Mean & 72.91 & 58.253 & 87.33 & 70.59 & 45.58 & 29.21 & 20.2 & 23.05 & 25.57 & 52.06 & 62.23 & 55.31 & \\
\hline
\end{tabular}

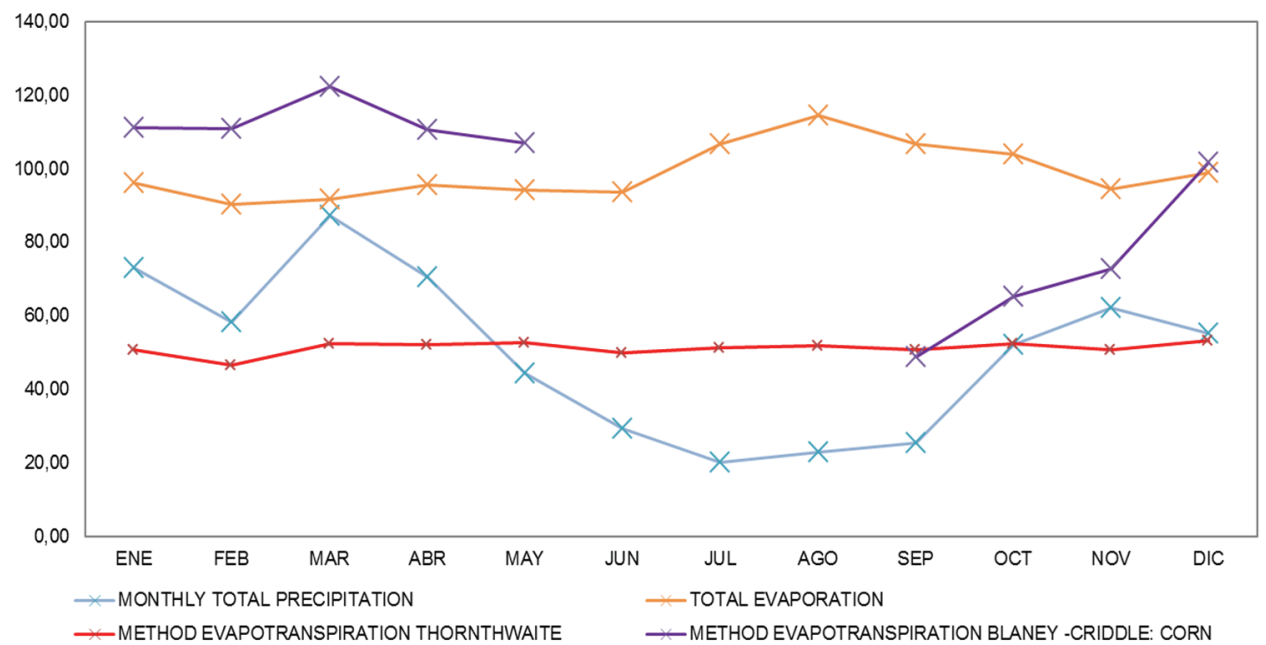

Figure 4. Curves for precipitation, evaporation, and evapotranspiration for maize for the period of one year.

1950). Precipitation in the area is lower than evapotranspiration and evaporation and therefore does not satisfy the water demand for maize (fig. 4). Therefore, the installation of fog catchers was justified to meet the water needs of the community.

\section{CATCher Prototypes IN 2014 AND 2015}

The locations of the prototype fog catchers installed in 2014 are shown in figure 5. Several of these fog catchers needed to be relocated in 2015 due to wind damage. The fog catchers stood $2 \mathrm{~m}$ high and were vulnerable to strong winds. The relocations were also necessary to provide better positions for fog catching. The new locations are also shown in figure 5 .

The 2015 prototypes were placed at a height not exceeding $1.5 \mathrm{~m}$ for better stability (fig. 3). These fog catchers each collected 1 to $4 \mathrm{~L}$ of water per day. The performance of the 2014 prototypes is shown in table 2 . These fog catchers were tested from November 2014 to March 2015, and the test results caused us to relocate prototypes $\mathrm{P} 1$ and $\mathrm{P} 2$ because they did not work properly. The relocation of these prototypes allowed us to collect more water, as shown in table 3.

\section{COMMUNITY SURVEY}

The survey administered to the community allowed us to determine the water needed for agricultural production throughout the year. It also provided the information needed to determine the size of the fog catcher system required to meet the water needs of the community. Most of the families grow maize and potatoes and, to a lesser extent, barley, rye, oats, wheat, onions, broad beans, and quinoa. They also raise small animals, such as chickens, pigs, sheep, and guinea pigs, as well as large animals, including milk cows, horses, and donkeys. This livestock serves either as working animals or for the purpose of sustenance.

Because most of the families in the community grow 


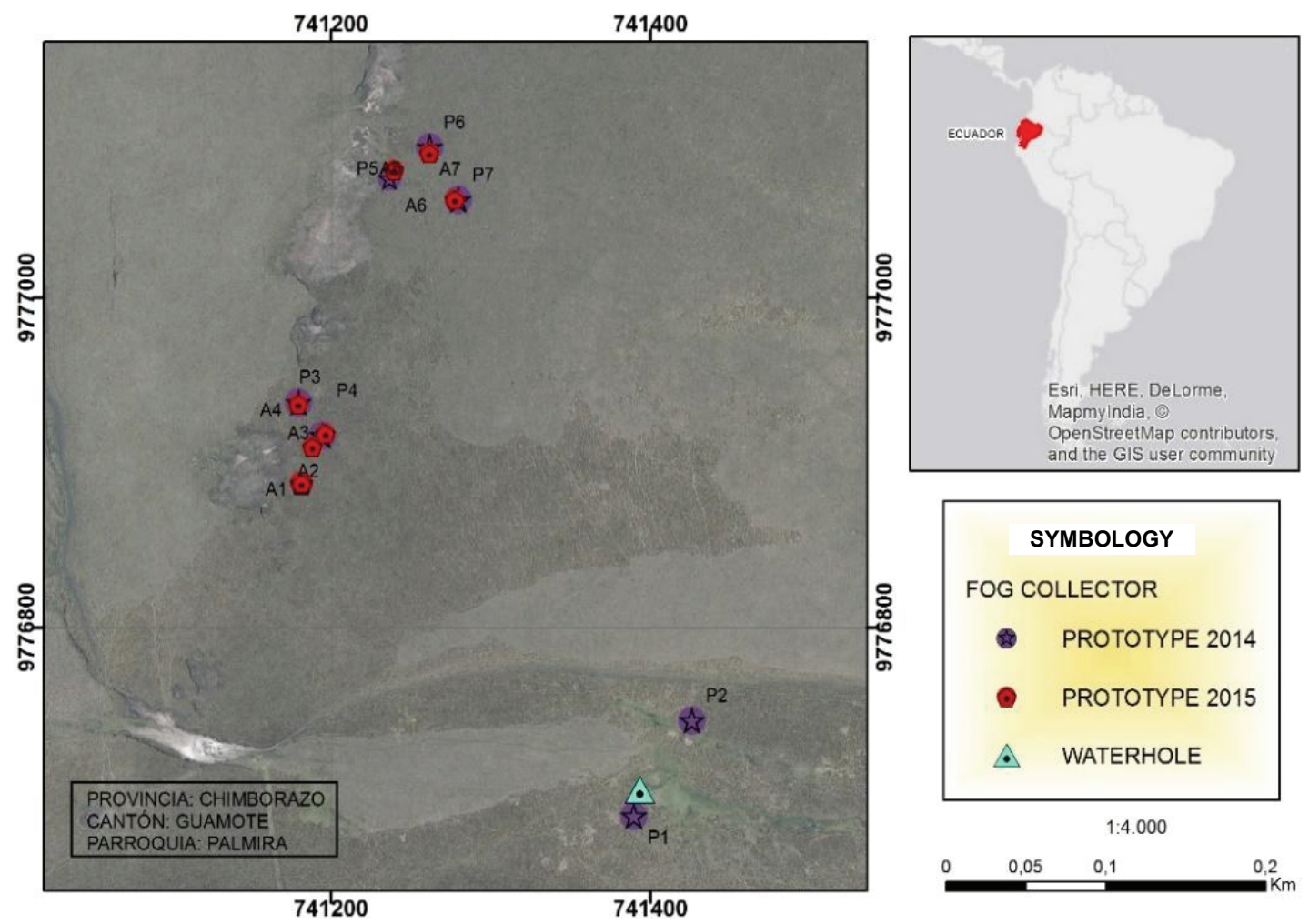

Figure 5. Locations of prototype fog catchers in 2014 and their relocation in 2015.

Table 2. Total water collected from November 2014 to March 2015.

\begin{tabular}{|c|c|c|c|c|c|c|}
\hline \multirow[b]{2}{*}{$\begin{array}{c}2014 \\
\text { Prototype }\end{array}$} & \multicolumn{5}{|c|}{$\begin{array}{c}\text { Average Water Collected } \\
\left(\mathrm{L} \mathrm{month}^{-1}\right)\end{array}$} & \multirow{2}{*}{$\begin{array}{c}\text { Total } \\
\text { Water } \\
\text { Collected } \\
\text { (L) }\end{array}$} \\
\hline & $\begin{array}{l}\text { Nov. } \\
2014\end{array}$ & $\begin{array}{l}\text { Dec. } \\
2014\end{array}$ & $\begin{array}{l}\text { Jan. } \\
2015\end{array}$ & $\begin{array}{l}\text { Feb. } \\
2015\end{array}$ & $\begin{array}{l}\text { Mar. } \\
2015\end{array}$ & \\
\hline P1 & 7.0 & 14.0 & 9.0 & 11.0 & 10.0 & 51.0 \\
\hline P2 & 19.0 & 16.0 & 11.0 & 12.0 & 12.0 & 70.0 \\
\hline P3 & 18.5 & 27.0 & 17.0 & 21.0 & 15.0 & 989.5 \\
\hline P4 & 30.0 & 29.0 & 21.0 & 25.0 & 19.0 & 124.0 \\
\hline P5 & 13.0 & 24.0 & 15.0 & 20.0 & 17.0 & 89.0 \\
\hline P6 & 16.0 & 23.0 & 13.0 & 17.0 & 15.0 & 84.0 \\
\hline P7 & 25.0 & 29.0 & 15.0 & 18.0 & 15.0 & 102.0 \\
\hline
\end{tabular}

Table 3. Total water collected from December 2015 to January 2016.

\begin{tabular}{|c|c|c|c|c|}
\hline \multirow[b]{2}{*}{$\begin{array}{c}2015 \\
\text { Prototype }\end{array}$} & \multicolumn{3}{|c|}{$\begin{array}{c}\text { Average Water Collected } \\
\left(\mathrm{L} \mathrm{month}^{-1}\right)\end{array}$} & \multirow{2}{*}{$\begin{array}{c}\text { Total } \\
\text { Water } \\
\text { Collected } \\
\text { (L) }\end{array}$} \\
\hline & $\begin{array}{l}\text { Dec. } \\
2015\end{array}$ & $\begin{array}{l}\text { Jan. } \\
2016\end{array}$ & $\begin{array}{l}\text { Feb. } \\
2016\end{array}$ & \\
\hline A1 & 160.0 & 500.0 & 560.0 & 1220.0 \\
\hline A2 & 160.0 & 500.0 & 560.0 & 1220.0 \\
\hline A3 & 160.0 & 500.0 & 560.0 & 1220.0 \\
\hline A4 & 160.0 & 500.0 & 560.0 & 1220.0 \\
\hline A5 & 38.0 & 484.0 & 560.0 & 1082.0 \\
\hline A6 & 160.0 & 500.0 & 560.0 & 1220.0 \\
\hline A7 & 160.0 & 500.0 & 560.0 & 1220.0 \\
\hline
\end{tabular}

maize and potatoes, we estimated the water requirements of these two crops, as shown in table 4. Potatoes can be grown through the rainy and dry seasons. Maize can be grown only in the rainy season. In addition, maize has the highest water requirement of all crops grown in the region. Therefore, meeting the water requirement for maize would also meet the water requirement for any other crop.

\section{DESIGN OF Fog CATCHER SySTEM}

The design of the fog catcher system was based on the
Table 4. Water requirements for potatoes and maize.

\begin{tabular}{ccccc}
\hline \multirow{2}{*}{ Table 4. Water requirements or potatoes and maize. } \\
\cline { 3 - 5 } & & \multicolumn{3}{c}{ Water Requirement for 1 ha } \\
\cline { 2 - 5 } Ponth & $\mathrm{mm} \mathrm{d}^{-1}$ & $\mathrm{~m}^{3} \mathrm{ha}^{-1} \mathrm{~d}^{-1}$ & $\mathrm{~L} \mathrm{~s}^{-1} \mathrm{ha}^{-1}$ \\
\hline Pry season & Apr. & 2.19 & 21.89 & 0.25 \\
& May & 4.18 & 41.78 & 0.48 \\
& June & 4.86 & 48.62 & 0.56 \\
& July & 4.50 & 45.00 & 0.52 \\
\hline Potatoes, & Sept. & 2.17 & 21.69 & 0.25 \\
rainy season & Oct. & 4.17 & 41.67 & 0.48 \\
& Nov. & 4.89 & 48.87 & 0.57 \\
& Dec. & 4.60 & 46.03 & 0.53 \\
\hline Maize & Jan. & 3.59 & 35.88 & 0.42 \\
& Feb. & 3.96 & 39.59 & 0.46 \\
& Mar. & 3.95 & 39.46 & 0.46 \\
& Apr. & 3.69 & 36.85 & 0.43 \\
& May & 3.45 & 34.52 & 0.40 \\
& Sept. & 1.63 & 16.27 & 0.19 \\
& Oct. & 2.1 & 21.02 & 0.24 \\
& Nov. & 2.43 & 24.25 & 0.28 \\
& Dec. & 3.28 & 32.77 & 0.38 \\
\hline
\end{tabular}

amount of water needed for crop production, as determined by the Blaney-Criddle method (Blaney and Criddle, 1950). The water volume from effective rainfall in the area was used to calculate the extraction of stored water for irrigation, leading to the additional amount of water required for maize (Aguilera and Martinez, 1996).

The volume of water collected daily by each of the prototype fog catchers was about $38.14 \mathrm{~L}$, or an average of $5.45 \mathrm{~L}$ of water collected daily per $\mathrm{m}^{2}$ of catcher area. The first two columns in table 5 list the amount of water needed to meet the crop demand as a percentage and in liters, while the third column lists the catcher area needed to collect the required amount of water. With these data, the size and number of fog catchers to place in the study area was determined. These data also allowed us to design extended fog catchers, as 
Table 5. Dimensions of the fog catcher system based to the water requirements for maize.

\begin{tabular}{|c|c|c|c|c|c|c|}
\hline \multirow{2}{*}{$\begin{array}{c}\text { Percentage of } \\
\text { Water Collected } \\
\text { to Meet Demand } \\
(\%)\end{array}$} & \multirow{2}{*}{$\begin{array}{l}\text { Amount of } \\
\text { Water to } \\
\text { Collect } \\
\text { (L) }\end{array}$} & \multirow{2}{*}{$\begin{array}{c}\text { Catcher Area Needed } \\
\text { to Meet the Required } \\
\text { Water Percentage } \\
\left(\mathrm{m}^{2}\right)\end{array}$} & \multicolumn{4}{|c|}{$\begin{array}{c}\text { Dimensions of the Fog Catcher System Needed } \\
\text { to Meet the Required Water Percentage }\end{array}$} \\
\hline & & & $\begin{array}{l}\text { Length } \\
\text { (m) }\end{array}$ & $\begin{array}{l}\text { Height } \\
\text { (m) }\end{array}$ & $\begin{array}{c}\text { Total Area } \\
\left(\mathrm{m}^{2}\right)\end{array}$ & $\begin{array}{c}\text { No. of Catchers } \\
\text { to Place }\end{array}$ \\
\hline 100 & 289,202 & 53,064 & 10 & 6 & 60 & 884 \\
\hline 50 & 144,601 & 26,532 & 10 & 6 & 60 & 442 \\
\hline 25 & 723,00 & 13,266 & 10 & 6 & 60 & 221 \\
\hline 10 & 28,920 & 5,306 & 10 & 6 & 60 & 88 \\
\hline 5 & 14,460 & 2,653 & 10 & 6 & 60 & 44 \\
\hline 1 & 2,892 & 531 & 10 & 6 & 60 & 9 \\
\hline
\end{tabular}
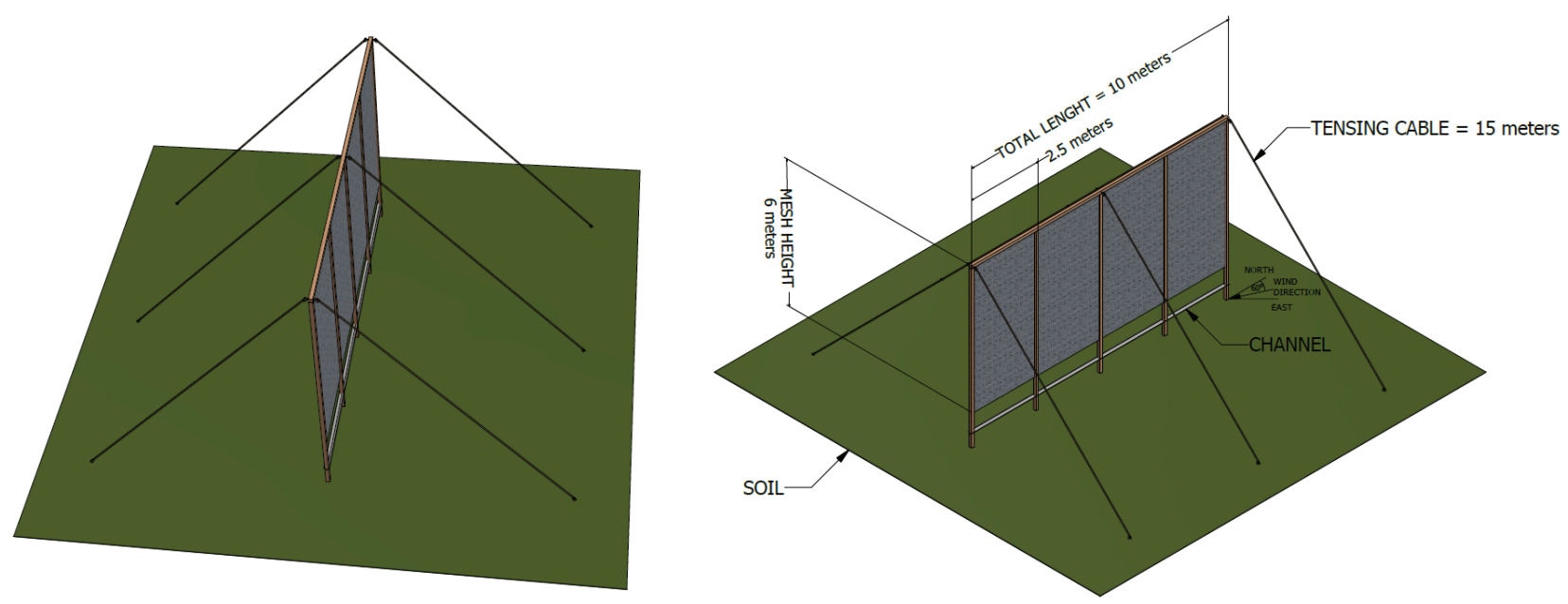

Figure 6. Top view (left) and front view (right) of a fog catcher.

shown in figure 6. To function optimally, the wind direction had to be taken into account, as each fog catcher must be perpendicular to the predominant wind direction.

The installation of the fog catchers created obvious visual pollution and may cause even an imbalance in the ecosystem. Therefore, we have most recently installed a 3D fog collector, named Urku Yaku, that is constructed with local material, including giant reeds.

\section{Conclusion}

Due to the lack of a regular water supply and water deficits in the Andean region of Ecuador, the installation of the fog catcher system has enjoyed a great reception from the local communities. The prototype fog catchers have obtained promising results, including daily water collection of 5 to $10 \mathrm{~L}$ for each fog catcher, and about $20 \mathrm{~L}$ per day during the rainy season. Therefore, the fog catcher system is clearly beneficial for the local communities.

In the future, the fog catcher system will supply $1 \%$ to $5 \%$ of the water demand, enough to meet the water needs for maize. This will help communities with inefficient irrigation systems and in areas with very low precipitation. The system will also compensate for water shortages. However, the fog catcher system will probably not meet with the total water requirement of the study area, as the needed amounts of water are disproportionately high.

\section{REFERENCES}

Aguilera, M., \& Martínez, R. (1996). Relaciones agua, suelo, planta, atmósfera. Universidad Autónoma Chapingo. Chapingo, Mexico: Universidad Autónoma Chapingo.

Aparicio, F. (2012). Fundamentos de hidrología de superficie. Mexico City, Mexico: Editorial Limusa.

Palmira. (2015). Development plan of and territorial ordering of Palmira parish. Guamote, Chimborazo Province, Ecuador: Autonomous Government of Palmira.

Blaney, H. F., \& Criddle, W. D. (1950). Determining water requirements in irrigated area from climatological irrigation data. Technical Paper No. 96. Washington, DC: USDA Soil Conservation Service.

Carrera-Villacrés, D., Guevara, P., Tamayo, O., Balarezo, A., Narvaez, C., \& Morocho, D. (2016). Relleno de series anuales de datos metereológicos mediante métodos estadísticos en la zona costera e interandina del Ecuador, y cálculo de la precipitación media. Idesia (Arica), 34(3), 81-90. https://doi.org/10.4067/S0718-34292016000300010

Cavelier, J., Solis, D., \& Jaramillo, M. A. (1996). Fog interception in montane forests across the central cordillera of Panama. $J$. Trop. Ecol., 12(3), 357-369. https://doi.org/10.1017/S026646740000955X

Cereceda, P., Hernandez, P., Leiva, J., \& de Dios, J. (2014). Agua de niebla: Nuevas tecnologías para el desarrollo sustentable en zonas áridas y semiáridas. Santiago, Chile: Corporación de Fomento de la Producción.

FogQuest. (2005). Sustainable water solutions. Kamloops, British Columbia, Canada: FogQuest. Retrieved from http://www.fogquest.org/

Frigerio, G. (1990). Informe interno a Pontificia Universidad Católica de Chile "Proyecto Omán”. Santiago, Chile: Pontificia Universidad Católica, Instituto de Geografica.

Fuzzi, S., Orsi, G., Bonforte, G., Zardini, B., \& Franchini, P. L. 
(1997). An automated fog water collector suitable for deposition networks: Design, operation, and field tests. Water. Air. Soil Pollut., 93(1), 383. https://doi.org/10.1007/bf02404768

Hering, S. V., Blumenthal, D. L., Brewer, R. L., Gertler, A., Hoffmann, M., Kadlecek, J. A., \& Pettus, K. (1987). Field intercomparison of five types of fog water collectors. Environ. Sci. Tech., 21(7), 654-663. https://doi.org/10.1021/es00161a006

IGM. (2013). Capas de información geográfica básica del IGM de libre acceso. Escala 1:50.000, segunda versión. Quito, Ecuador: Instituto Geográfico Militar. Retrieved from http://www.geoportaligm.gob.ec/

INAMHI. (2015). Anuarios meteorológicos. Área de meteorología. Quito, Ecuador: Instituto de Meteorología e Hidrología. Retrieved from http://www.serviciometeorologico.gob.ec/

Jaen, M. V. M. (2002). Fog water collection in a rural park in the Canary Islands (Spain). Atmos. Res., 64(1), 239-250. https://doi.org/10.1016/S0169-8095(02)00095-9

Mousavi-baygi, M. (2008). The implementation of fog water collection systems in northeast of Iran. Intl. J. Pure Appl. Phys., $4(1), 13-21$.

Olivier, J. (2002). Fog-water harvesting along the west coast of South Africa: A feasibility study. Water $S A, 28(4), 349-360$. https://doi.org/10.4314/wsa.v28i4.4908

Otero, G. D. (2011). Imputación de datos faltantes en un sistema de información sobre conductas de riesgo. MS thesis. Santiago de Compostela, Spain: Universidad de Santiago de Compostela.

Pajares, P., Eckert, S., Berrahmouni, N., Kohler, T., Maselli, D., \& Zelaya, S. (2011). Highlands and drylands: Mountains, a source of resilience in arid regions. Rome, Italy: United Nations FAO, Centre for Development and Environment (CDE).

Pinche, C., \& Ruiz, L. (1996). Fog on the brine: Fog-catching systems for arid lands. Waterlines, 14(4), 4-7. https://doi.org/10.3362/0262-8104.1996.013

Regalado, C. M., \& Ritter, A. (2016). The design of an optimal fog water collector: A theoretical analysis. Atmos. Res., 178-179, 4554. https://doi.org/10.1016/j.atmosres.2016.03.006

Ritter, A., Regalado, C. M., \& Aschan, G. (2008). Fog water collection in a subtropical elfin laurel forest of the Garajonay National Park (Canary Islands): A combined approach using artificial fog catchers and a physically based impaction model. $J$.
Hydrometeorol., 9(5), 920-935. https://doi.org/10.1175/2008jhm992.1

Schellekens, J., Bruijnzeel, L. A., Wickel, A. J., Scatena, F. N., \& Silver, W. L. (1998). Interception of horizontal precipitation by elfin cloud forest in the Luquillo Mountains, eastern Puerto Rico. Proc. 1st Intl. Conf. on Fog and Fog Collection (pp. 2932). Kamloops, British Columbia, Canada: FogQuest.

Schemenauer, R. S., \& Cereceda, P. (1991). Fog-water collection in arid coastal locations. Ambio, 20(7), 303-308.

Schemenauer, R. S., \& Cereceda, P. (1992). The quality of fog water collected for domestic and agricultural use in Chile. $J$. Appl. Meteorol., 31(3), 275-290. https://doi.org/10.1175/15200450(1992)031<0275:tqofwc $>2.0 . c 0 ; 2$

Schemenauer, R., Cereceda, P., \& Osses, P. (2005). FogQuest: Fog water collection manual. Kamloops, British Columbia, Canada: FogQuest.

Shanyengana, E. S., Henschel, J. R., Seely, M. K., \& Sanderson, R. D. (2002). Exploring fog as a supplementary water source in Namibia. Atmos. Res., 64(1), 251-259. https://doi.org/10.1016/S0169-8095(02)00096-0

Suau, C. (2010). Fog collection and sustainable architecture in Atacama coast. Proc. 5th Intl. Conf. on Fog, Fog Collection, and Dew (pp. 179-188). Münster, Germany: University of Münster, Climatology Working Group.

Thornthwaite, C. W. (1948). An approach toward a rational classification of climate. Geograph. Rev., 38(1), 55-94. https://doi.org/10.2307/210739

WMO. (2011). Guía de prácticas climatológica. WMO No. 100. Geneva, Switzerland: World Meteorological Organizatoion. Retrieved from http://www.wmo.int/pages/prog/wcp/ccl/guide/documents/wmo _100_es.pdf

Williams, A. (2015). Peru: Capturing "oceans in the sky". Water Wastewater Intl., 3(3). Retrieved from http://www.waterworld.com/articles/wwi/print/volume-30/issue3/regional-spotlight-latin-america/peru-capturing-oceans-in-thesky.html

Wilson, E. M. (1974). Engineering hydrology. London, UK: McMillan. https://doi.org/10.1007/978-1-349-02417-9 